\title{
MATERIALS, FORENSICS AND FEMINIST GEOPOLITICS
}

\section{Forthcoming in Progress in Human Geography}

Jo Sharp

School of Geography and Sustainable Development

University of St Andrews, UK

...the heirs of the Enlightenment...defined a parliament of mutes, the laboratory, where scientists, mere intermediaries, spoke all by themselves in the name of things. What did these representatives say? Nothing but what the things would have said on their own, had they only been able to speak. (Latour 1993: 142).

I have seen many strange things, but where shall be seen a thing stranger than this? ... Two lusty porters brought to the witness stand sundry big boxes containing the mortal remains of the woman: they were packed in jars, cigar boxes, paper boxes, tin pails; there were fragments of bones, fibres steeped in grisly solutions; anomalous dung and granules, pieces of rags and cloth...but there, all the time, sat grave professors in the witness chair, interpreting and recounting until, as you listened, the dry bones and dust took on form and like; the rags grew into garments, the garments were fitted on the figure. (Julian Hawthorne on the Leutgart Murder Case of 1857, from McDermid (2014)).

\section{I: INTRODUCTION}

In 2001, Dowler and Sharp (2001: 171) wrote that in order "to start to think in terms of a feminist geopolitics, it is necessary to think more clearly of the grounding of geopolitical discourse in practice (and in place) - to link international representation to the geographies of everyday life; to understand the ways in which the nation and the international are reproduced in the mundane practices we take for granted." They sought to put the body at the heart of geopolitics as a counterbalance to the overwhelmingly discursive nature of critical geopolitics at the time, an ambition shared by others ascribing to the feminist geopolitics approach (see, especially, Hyndman 2001). This was not a proposal for a non-representational geopolitics but a feminist geopolitics that combined an attentiveness both to political representations and practice. While there was an implicit materiality to this call for feminist geopolitics, it was not developed.

The opening quote from Latour's (1993) influential We have never been modern, highlights the importance of bringing the material, qua material, into social and political theory. This is something that has been sought in recent moves towards more-than-human, post-humanist and assemblage theories of the international (Barry 2013b; Dittmer 2014; Dixon 2015; Last 2015; Kinkaid forthcoming). And yet, feminism is always attentive to political inequalities and issues of social justice - dynamics that, while material in process and effect, are also suffused with representational politics. Thus, the second opening quote, drawn from a recent popular book on the history of forensics, starts to hint at the usefulness of an approach that recognises the performative nature of 
forensics as a foundation for a feminism that is both attentive to materialist and more-than-human critiques, and recognises the power of particular authoritative representations of the body.

This paper seeks to advance the case for a materialist feminist geopolitics that recognises the challenges both to the enlightenment individual and the discursive turn in geography that new materialist approaches pose, but one that also wants to foreground a progressive feminist politics that is attentive to the ways in which the material is both shaped and placed by the representational, while at the same time shaping and placing it.

\section{II: FEMINIST GEOPOLITICS}

From its inception, feminist geopolitics has been driven by a desire for justice. It has sought to extend the feminist critique of divisions of the domestic and the public through the performance of international politics, to highlight the significance of supposedly non-political spaces and processes in the making of geopolitics, the enforcement of borders and identities, and the exclusion and marginalization of a variety of Others. A number of feminist scholars have argued for the importance of grounding the discursive focus of critical geopolitics in the lived and embodied realities of those impacted by geopolitics and, through their everyday actions, those who make geopolitics (Dowler and Sharp 2001; Hyndman 2001; Fluri 2009; Pain 2014). Feminist geopolitics has been critical of the elitism of accounts that are overly dependent upon the textual, especially the texts of political elites, wanting instead to include a variety of practices into the remit of critical geopolitics, and has responded to the perceived distancing and elitism of critical and traditional forms of geopolitics by foregrounding the testimony of lived experience.

Much of the resulting work sought to render visible the impacts of the geopolitical on the bodies of those normally hidden from geopolitical analysis, highlighting the impacts of the geopolitics of war and development, the experiences of asylum-seekers and refugees, and the experiences of women in the military itself and in militarized landscapes across the west and elsewhere (see, for example, Fluri 2009; Dowler 2002; Brickell 2012). Instead of thinking about popular geopolitics as the way in which geopolitical practice escapes the formal realms of statecraft, academia and think-tanks, Woodyer and Carter (forthcoming) suggest we instead reframe our inquiry around the domestication of geopolitics. This brings the feminist geopolitical critique of critical geopolitics front and centre, as the concept of "domesticating" draws our attention to the ways in which divisions between public and private are inscribed on the international-domestic political landscape in the same ways in which public-private is inscribed into the everyday: the dangers of the public/international are set against the protection offered by patriarch/state in the domestic spaces. Considering the domestic as an important space therefore overturns any attempt to suggest that certain activities are outside of politics, whether the politics of society or the geopolitics of the international. 
However, while feminist geopolitics embeds the consequences and impacts of geopolitical processes into everyday spaces providing a clear sense of the power of hegemonic geopolitics to inscribe identities and morality onto the bodies of various communities, this is often presented (most often implicitly) as a one-way process. Although this has brought a richness and lived quality to their interpretations of geopolitics, perhaps because of a fear of grand theorising or falling into the same God's-eye position the critical geopolitics has been critiqued for (Sharp 2000), this focus on the material and embodied has meant a shift of attention away from the other 'end' of the geopolitical spectrum, i.e. the production and mechanisms of domination of the global geopolitical gaze and of dominant subjectivities. While efforts to suggest conceptually that the everyday and global are fundamentally entangled, that the global and intimate are not only linked but are an indivisible continuum (Pain 2014; Pratt and Rosner 2012), the focus is most often of examples where (powerful) geopolitics is imposed upon (weak) bodies, rather than on (powerful) bodies actively making geopolitics. Thus, while there is considerable work that reveals the ways in which geopolitics is domesticated and brought into the home and the intimate spaces of the everyday, there is much less attention given to how these intimate practices serve to constitute the geopolitical as a presence at other putative scales.

This debate about the "where" of geopolitics has been at the centre of debate since the initial discussions of "critical geopolitics" as an approach. Simon Dalby has, for instance, taken Nigel Thrift (2000) to task for his insistence on a focus on "the little things" at the expense, Dalby argues, of "the big things":

Thrift wants critical geopolitics to do all sorts of things, but not it seems, engage in the critique of the reasoning practices of intellectuals of statecraft, whether in terms of formal geopolitical reasoning, or the more practical versions in media and political discourse.... While Thrift (2000) may have no interest in tackling the conceptual infrastructure of military violence, in abandoning this critical edge his suggested agenda eviscerates the political purpose of critical geopolitics precisely ... by leaving out the "big things" (Dalby 2010: 282).

While feminist geographers have insisted on the very inseparability of the "little" and "big" things, given the nature of the understanding of the power of the geopolitical noted above Dalby's insistence on the need always to foreground the connections between apparently little and big things is worth further reflection. The initial intention of a specifically critical geopolitics - as opposed to a critical political geography - was not that only the international sphere was of significance, but to always understand the ways in which representation and practice at a variety of scales are entangled with global imaginaries, most notably global imaginaries of violence.

There are insightful feminist examples of just such a critical geopolitics, perhaps most notably Sara Koopman's (2011) feminist conceptualisation of alter-geopolitics. Koopman explores "protective accompaniment," a political intervention whereby those with secure bodies (generally privileged, 
white, western bodies) accompany insecure bodies (typically those who are at risk from their own government) as they make dangerous travel. The "valued" body, through its immediate proximity to the insecure body offers protection, as the international geopolitical consequences of the "valued" body being injured in an attack would be significant for the aggressor. Koopman calls this alter-geopolitics because it is an active stepping away from any formal geopolitics or academic critique of it, but there is a clear feminist trajectory here with the protectors aware of, and critical of, the privilege their bodies carry. They harness this contradiction to protect those whose bodies are not secure - their political tactics are dependent upon the very entanglement of the globalintimate that feminist geographers have explored seeing bodies as constructive of state and global geopolitical relations as well as being impacted by them.

Others have sought to transcend the binary language of "little" and "big", through the figure of assemblage. In his “assemblage geopolitics," Dittmer (2014: 388-389) has explained, "because power is enacted through assemblage, it must be understood as distributed among the various components of that assemblage, human and non-human." Just as with feminist geopolitics, this challenges the spatial hierarchies projected through geopolitical discourse, insisting that the question of scale be replaced by a sense of connectivity as Dittmer (2014: 390) puts it, "When the anthropocentrism of geopolitical thought (whether critical or otherwise) is replaced with a wider notion of the political, we are left with a flat ontology whereby so-called 'macro' scales emerge out of interactions occurring at relatively 'micro' scales". Dittmer acknowledges that humans differ from "(most) non-human components in that they exercise intentionality and reflexivity, and this is crucial to any analysis. However," he continues, "it would be a mistake to see this as a fundamental difference, as this would disavow the embodied materiality of humanity that links us to the rest of the world" (Dittmer 2014: 389, emphasis in original). Going further, Dixon (2015: 113) proposes a move to "an approach to the embodied, geopolitical body that does not thereby presume an individuated corporeality," instead charting the potential capabilities of non-corporeal, or extracorporeal, flesh, refusing to limit citizenship and agency to whole bodies and instead seeing the potential for it these also to reside in fleshy parts, such as stem cells.

Indeed, such materialities are clearly significant in the political constitution of our world as is particularly evident in such discussions about the transformations of identities with technological advancement:

Genetically modified organisms now feed much of the world and fuel its vehicles; they seem destined to change forms of agricultural production and energy use irrevocably. Wondrous medical and digital prostheses, too, now enable, enhance, and enrich our physical and social lives in many ways. Whether it is pacing the heartbeat, dispensing medication, catching the news on a podcast, elaborating an internet-based community, finding directions via the web or GPS, or sending family love via wireless communications, 
digital technologies have become a part of our lives and of who we are (Coole and Frost 2010: 16).

However, Coole and Frost (2010:19) continue, "a second aspect of the new biomaterialism that we wish to draw attention to is an increasing acknowledgment within theories of politics-and especially in theories of democracy and citizenship—of the role played by the body as a visceral protagonist within political encounters". Thus, while these technologies undoubtedly do change relations, offering new exciting, transgressive and productive identities, subjectivities and possibilities, perhaps more important is an attentiveness to the uneven distribution of these new possibilities, because, as Kearns and Reid-Henry (2009: 555) have reminded us, "rather less novel and more mundane material inequalities exist alongside (and in some cases they are being reshaped by) the technological developments that preoccupy much of the recent literature on the politics of human life". It is predominantly the white, privileged bodies of the wealthy in the Global North that are presented with these technological possibilities, whether the health-promoting technologies of digital health monitoring and personalised medicines, or the mobility-enhancing possibilities of biometric identifications. For marginalised bodies, still caught up in the representational economies of race, gender, sexuality and class, such possibilities are very different and have a very different political effect. For instance, a number of authors have highlighted the fact that marginal bodies are selected - or indeed created, as "vile bodies" in need of monitoring to be on the front line of these new technologies (see Brown 2015; Jacobsen 2015). Refugees on the Afghan border, or those attempting to enter the EU, have faced the most comprehensive attempts to capture biometric information, based on the principle that the mind is deceiving, but the body is compelled to be truthful. ${ }^{i}$ Indeed, rather than talking of taking fingerprints or other biometric data, van der Ploeg insists this is a more invasive and constitutive process:

...if we focus on the body 'enrolled' in a biometric system, we may come to see how this body, in a sense, comes to be marked with stigmata - signs on the flesh...Signs, moreover, written by the authorities, that turn the individual's body into a witness against themselves (van der Ploeg 1999: 301)

This highlights a concern that assemblage thinking, given its 'emphasis on material politics, has abandoned "traditional" social categories such as class, gender and ethnicity". (Kinkaid forthcoming: 3). Instead, drawing on Puar (2017), Kinkaid (forthcoming: 6) argues that, "the manner in which race, gender, and sexuality organize material flows, political discourse, health outcomes, etc., is what makes assemblage a useful analytic".

I share this concern and want to make the case that a distinctly feminist geopolitics must have at its heart this concern for the representational politics of assemblage and the material; for, while at the core of feminism is a mistrust of any binaries - whether these are the spatial divisions of public and private or the more vital ones of the division between human and non-human matter - at the same time I want to argue here that what is an important possibility for feminist politics is the 
centrality of issues of social justice. And this is where my approach diverges from Dixon's. In her version of feminist geopolitics, Dixon (2015: 10) proposes "explorations of the plurivitality of the corporeal body, taking into account, for example, the work of inherited DNA, epigenetic influences, microbial viruses and bacteria, neural receptors, kinaesthetic sensitivities and so on, all of which subvert the idea of a sovereign subject in a fleshy container." This is a vision that draws on a different genealogy of feminist theory than the majority of feminist geopolitics. Finding inspiration in the feminism of Braidotti, Grosz, and Irigaray, Dixon's account challenges the enlightenment vision of an independent, self-knowing, coherent subject, building, of course, on a long tradition of feminism which wants us to recognise the ways in which we are all dependent upon others. But recognising our embeddedness within networks of other agents does not mean we have to lose a sense of the body as a locus for social justice at the heart of a progressive feminism. Such a progressive feminist politics - a politics that goes beyond critique towards thinking about how the world could be better - must have a wariness of the political impacts of any flattening of ontology in a world whose political topography is marked by intensely uneven power geometries (Massey 1993). As Kinkaid (forthcoming: 8) puts it, "unlike assemblage geographies, feminist thought is necessarily wedded to categories of difference and a concern with how the production of difference and identity is always already an operation of power [...] assemblage thinking fails to render visible the operations of power and is poorly equipped to address the question of how symbolic-material differentials are maintained and endure".

Thus, while agreeing with challenges to the enlightenment sense of coherent, bounded, and autonomous bodies as feminism has consistently argued, here I want to keep a sense of the body at the centre of feminist geopolitics precisely because it is through the differential positioning of bodies in different assemblages of things - and the very different representations of different sorts of bodies in these assemblages - that different capabilities and prospects emerge. Meehan, Shaw and Marston (2013:3) put this aptly in their 'political geographies of the object':

The point is not to adjudicate on the supposed reality of an object, but ask instead, how does it affect force relations? What work does it do? How does the object generate and transform power?

This draws our attention to the placement of non-human objects within networks of power. Objects do not just passively sit in place; they are force-full, but there is "an ontological unevenness" (Shaw 2012: 622) in this constellation of objects (see also Squire 2015).

In his consideration of how international relations could respond to the challenges of Actor Network Theory, Barry (2013b: 414) highlights the importance of relations between agents. In ANT, he argues, "the actor does not refer to an individual agent, but rather an entity whose existence depends upon their network of alliances within a shifting heterogeneous and expansive relational field". Thus, identity changes as it "enters into, or is enrolled or mobilised into, a field 
of relations with other entities" (Barry 2013b: 414). Barry (2013a) draws on Bruno Latour and Peter Weibel's 2005 exhibit, Making things public, to clarify the role of things in the political. The exhibit, in the aftermath of the 2003 invasion of Iraq by the US and its allies and claims that Saddam Hussein had weapons of mass destruction, built on Latour's earlier work to make a much more explicitly political statement about:

the critical importance of both materials and knowledge claims about materials in public political life $[. .$.$] Latour therefore understood politics, in part, as a process in which objects$ can become the locus of public disagreement. In this view, objects should not be thought of as incidental to politics, but as integral to the disagreements and disputes that lie at the heart of political life (Barry 2013a: 7).

This understanding of the creation of publics around the material, where objects create relationships between people (and other objects), presents a useful alternative way of understanding life as more than individual agency and subjectivity. This understanding of the way in which people and things are brought together in particular times and places as publics is perhaps a way to think about assemblages that is cognisant of the power of assemblages to shape and reinforce hierarchies. McLagan and McKee (2012: 9) regard political acts as

... encoded in material form - feet marching on a street, punch holes on a card, images on a television newscast, tweets about events unfolding in real time - by which the political becomes manifest in the world. These forms have force, shaping people as subjects and constituting the contours of what is perceptible, sensible, legible. In doing so, they define the terms of political possibility and create terrain for political acts.

In her proposal for a materialist geopolitics, Squire (2015: 148) seeks not to privilege the efficacy of matter, but instead to offer an approach based on the fact that individuals are always simultaneously individual and collective beings, always tied to a wider context beyond themselves as individuals. It is the collectivity that emerges through the material creation of publics - in particular spaces, at particular times - that I think brings in materialism to feminist geopolitics. Judith Butler's $(2012$; 2015) account also ensures that cognisance of its needs and capabilities are the focal point of such enrolment. This is not an entirely separated, unitary body, as she is conscious that its capacities are created through its connectivity and contextualisation with other actants:

Human action depends on all sorts of supports - it is always supported action. We know from disability studies that the capacity to move depends on instruments and surfaces that make movement possible and that bodily movement is supported and facilitated by nonhuman subjects and their particular capacity for agency. (Butler 2012: 118).

This is not a fully vitalist account. Material is not free to be itself when tied to bodies: theorists of gender and race make clear the stabilizing powers of dominant representation, the "socio-political 
process of differentiation and hierachization, which are projected onto the putatively human body" (Weheliye 2014: 5).

The above work insists on our attentiveness to the effects of such "sociopolitical processes of differentiation" in the creation of political publics. The next section will examine how these processes are articulated through the concept of forensics and the possibilities I see in this for a feminist geopolitics.

\section{III: FORENSICS}

By examining the states of identification and the layers of meaning attached to their results, we see the dynamic, multivalent aspects of the forensic effort alongside the intimate, powerful instances of recognition experienced by families of the missing [...] We see how memory and imagination intersect with biotechnology, exposing subjective experiences that permeate the identification process. We also learn the extent of its import - for families, Bosnian national politics, and international interventionism” (Wagner 2008: 2).

Sarah Wagner's introduction to the role of the emerging science of forensics in the aftermath of the Bosnian conflict at the close of the twentieth century outlines the entanglement of scales of identification and politics, and the interdependency of material and meaning; entanglements that explores the materialist feminist geopolitics that I have just outlined. The etymology of the word "forensics" comes from the Latin forensic, referring to "forum" (Wiezman 2012; np), hence highlighting its origin in the idea of how an argument is presented. But, as Eyal Weizman (2012:np) has highlighted, "it includes not only human speech but also that of things. ... Because objects cannot actually speak, there is a need for a "translator" or an "interpreter"- a person or a set of technologies to mediate between the thing and the forum". This distinction is an important result of changes to international geopolitical imaginations, a shift that feminist geopolitics must take account of.

In the 1990s the legalization of human rights in International Criminal Court (post Yugoslavia and Rwanda) saw a shift from the dominance of witness statements to "an emergent forensic sensibility, an object-oriented juridical culture immersed in matter and materialities, in code and form, and in the presentation of scientific investigations by experts" (Weizman 2012: np). Schuppli (2014: 289 and 292) calls this "material witness", by which she means:

...an entity (object or unit) whose physical properties or technical organization not only records evidence of passing events to which it can actively bear witness (the material crimescene evidence sequestered in the vaults of the OTP [Office of the Prosecutor], for example), but also the means by which the event of evidence is itself made manifest (the rules of procedure and evidence that govern the presentation of such materials in court and adjudicate over their admission into evidence). [...] These are materials that have come out of situations of political conflict and crisis [...] but they are also materials that have had violence done to them. Matter, in effect, only becomes a material witness when the 
complex histories entangled within objects are unfolded, translated, and transformed into legible formats that can be offered up for public consideration and debate.

These complex histories are enfolded through scalar entanglements of the global-state-intimate. The Balkan conflict presented a new kind of atrocity: secondary mass graves were established within which body parts, fragments of bone and DNA were mixed together. This was a new technology designed to cover up war crimes (Wagner 2008: 84). During the transfer from initial to secondary mass grave, bodies were often broken up, sometimes parts of the same body ended up in multiple secondary sites. This led to new technologies of investigation, but perhaps more importantly, the creation of publics for the performance of forensics:

Around their bones a public (Latour 2005) has formed that increasingly relied on genetics to establish evidence of individual identity and, thereby, the concrete facts of numbers and names of victims. This effort requires collecting, cataloguing, and storing massive amounts of data - that is, the re-presentation of bits and pieces of individuals' lives into Excel spreadsheets and computer database windows. Gradually, this public has generated a bureaucracy of post-mortem individual identity, not only through the genetic profits but also through compact portraits of the missing and their relatives as donors of blood samples....Science and memory combine forces, connecting the narratives of the missing with the stories unfolded by sets of genetic codes. (Wagner 2008: 13)

Objects - personal effects but also DNA matches and bone fragments - come literally to embody the missing for their relatives. But, what is key is that these various narrative, genetic, technological and scientific parts, while fitting Latour's concept of a parliament of things, are animated and made meaningful through the recreation of whole bodies: as Wagner (2008: 14) asks, "Does the identification of a partial body signal the end of absence, or an incomplete presence?"

...a person's head and all that it entails - his face, his eyes, the full range of emotions expressed on these features - more than any other part of the physical remains, embody the character of the missing person. Absence of a skull makes the identification extremely traumatic if not impossible for some family members to accept (Wagner 2008: 179).

It is not only in forensic scientists' accounts that we see this turn to material witnesses. Popular accounts of conflicts have explored the things that are changing the relationship between human bodies and other actants in war, and the embodied effects of this. Castner (2016) sets out to examine the supply chain of the IED that killed his friend in Afghanistan, but ends up tracing an assemblage of things that ranges from weapons and opiates in Afghanistan to the prosthetics and dogs that support soldiers' rehabilitation back in the US.

In his account of the American war in Vietnam, Tim O'Brien similarly draws of on the materiality of being a soldier in the tropical forest, creating descriptions that create an assemblage of landscape, the human, and inanimate things: 
We walked along. Forward with the left leg, plant the foot, lock the knee, arch the ankle. Push the leg into the paddy, stiffen the spine. Let the war rest there atop the left leg; the rucksack, the radio, the hand grenades, the magazines of golden ammo, the rifle, the steel helmet, the jingling dog-tags, the body's own fat and water and meat, the whole contingent of warring artifacts and flesh. Let it all perch there, rocking on top of the left leg, fastened and tied and anchored by latches and zippers and snaps and nylon cord. Packhorse for the soul. (O’Brien cited in Beauchamp 2016:np)

Former British Army Captain Harry Parker's Anatomy of a Soldier is an even more clearly “object oriented ontology of war" (Beauchamp 2016: np), which narrates the experiences of a soldier who loses his legs in an explosion in Afghanistan from the point of view of the variety of things that create him as a soldier, that are used to construct the device that injures him, and then that support his body in his recovery. Each chapter is written from the perspective of a different object. The chapters written as an IED, syringe, bullet, prosthetics, fertiliser, a handbag ... enable intersubjective abilities, constructing both the body of war and the body created/destroyed by war (and also the reader's relationship with the soldier - sometimes passively observing, at other times viscerally connected). One chapter, set in the hospital in England narrates:

Seven days and four thousand miles after I had been inserted into you, you changed. They weren't expecting it but your eyes flickered and your tongue started to push against me as you gagged around my pipe.... You were mumbling and confused as I passed your teeth. I was left on the table and the man and women were brought back in to be with you. She held your hand. You recognised her and your relationship to them both. A nurse picked me up, pushed the foot pedal of a bin and threw me into a yellow surgical waste bag. I was no longer part of you. (Parker 2016: np)

Beauchamp (2016: np) argues that not only do objects help to narrative Parker's tale, "they also bear semiconscious witness to our shared reality, corroborating it." We too are created as a public around the objects that narrate Parker's biography.

These accounts show the range of things needed to enable, animate, facilitate war; but also what enables, animates, facilitates the bodies of soldiers. The things that narrate Parker's story highlights Butler's (2012) arguments about the importance of understanding the abilities and precarities of the body, while also seeing it as being dependent for its being on other things. Despite the dispersed nature of the narrative moving from the perspective of one thing to another, just as with the case of the Balkans discussed above, the body is always at the centre.

But this is not to imply a naïve notion of a biological body, rather like the forensics work referenced above it is an assemblage of bodies and things. Clea Koffs (2004: np) account of her forensic anthropological work in Rwanda and the former Yugoslavia:

I was told that many of them wouldn't accept anthropological identifications, didn't care that the body matched their relative down to the number of teeth missing from years before or a healed fracture, on top of being the right age, height and sex. What those 
women did respond to were the artefacts-again, items forensic scientists consider only presumptive identifiers. One woman believed when she saw the front-door key to her old apartment, found in the pocket of the trousers worn by the man anthropologically identified as her husband.

These intertwined material witnesses, entangled the domestic, state and international in ways that closely match the ambitions of feminist geopolitics. To return to Koff (2004: np):

You see, because the inhabitants of Srebrenica lived under siege for several years, they didn't have access to new clothes, so the women had repaired the same garments, month after month. Thus, they could recognise their own stitches, could describe the type of mending they did and what material they used, and where exactly they made the mends. And in the morgue we found that where, say, head hair was no longer present on a body, a triangular fabric patch was still holding together the inside of a trouser pocket, the colour of the thread still vibrant, like a beacon illuminating the varied stitchwork that could identify whose trousers they were. With this evidence, in combination with the anthropological analysis of the body wearing the trousers, an identification might be made. As in Rwanda, clothing on its own could only form a presumptive identification (it is only worn on the body, not intrinsic to the body), but the particular conditions of war and deprivation in Srebrenica imbued the clothing with greater significance.

Again, then, the politics of these technological assemblages highlight the significance of the meanings attached to material as part of a body. However, while forensics can be a helpful lens through which to think through feminist geopolitics, it needs to be considered critically - the publics it creates, particularly, need close attention. Rosenblatt (2015: 28-29) notes the discomfort felt by many forensic professionals at, "the effort and expense spent on the identification of relatively light-skinned bodies in countries considered part of (or on the doorstep of) the West, compared with the effort and expense put into identifying dark-skinned bodies in non-Western countries." It must not be forgotten that forensic anthropology is a form of physical anthropology, focused largely on the human skeleton. This allows them to assemble skeletons and analyse their 'biological profile': "age, sex, stature, and ancestry or sometimes race, as well as detecting signs of physical trauma and disease" (Rosenblatt 2015: 14-15). This draws on exactly the structural approach of racist colonial anthropology, and creates ambivalent spaces for the (white) practice of forensics in ex-colonial locations: "As the bodies of historically colonized and subjugated people are lifted out of the earth and placed in the care of international scientific experts, also present in the minds of many is the legacy of colonialism's particular attentiveness to the bodies of its subjects their exhibition, categorization, study, and regulation, and in many cases the disturbance of their final rest" (Rosenblatt 2015: 7). This optics of forensics is not insignificant. The spectacular visuals of US drone attacks, for instance, are replicated in the aesthetics of Weizman's (2011, 2012. 2017) forensic architecture, a troubling "combination of passivity (just watching) and aggressivity (the militarized view)" (Kurgan 2013: 29). Many forensic anthropologists themselves fear their own techniques replicate the violence of the act they seek to uncover (see Koff 2004). 
Yet, what I find helpful about forensics - absolutely not as another hyphenation for geopolitics but as a way of doing feminist geopolitics - is that is helpful in finding new possibilities for feminist understandings of the ways in which bodies and other materialities are caught up in geopolitics. At the same time, however, it recognises the performative instances, the particular institutional locales, and, perhaps most important, the creation of political publics through which these networks of materialities are made to matter. ${ }^{\mathrm{ii}}$

\section{IV: CONCLUSION}

Forensics' focus on material witnesses (Schuppli 2014) being brought into the forum is not a fully realised vital materiality. But, if we are talking about political geography, critical geopolitics or feminist geopolitics, then is this not what we are talking of? The forum of politics must include people and things, but we must recognise the ways in which the things are brought into the political; through debate, challenge, argument. For this reason, I do not believe critical geopolitics can ever escape the discursive. The material here is the more-than-representational (Lorimer 2005), rather than non-representational. And the things are represented in the ways in which they are constituted to form bodies.

This is, then, a limited recognition of the agency of things, but it's one that I think this is a helpful way of thinking about the tensions between the multiple materialities that make up the world with the professional (and quotidian) practices that bring these into our political lives in ways that trace connections between body-parts, bodies, states and the global ambitions of geopolitical practices (as articulated by Dalby 2010).

The international politics of justice, most especially in dealing with war crimes, has undergone a material turn, what has been referred to as a shift from testimony to the object. Such objects do not naively speak for themselves, of course, and so new political spaces are opening up, with new advocates for those the objects represent. It is important to respond to these new narratives, and to think of the geopolitics that emerges from this changing context. In a review of the Forensic Architecture group, Gordillo (2015: 382) applauds the way it documents the violence of the state and corporate crimes of the imperial present: "This is a gaze finely attuned to the negativity of matter, sensitive to the many ways in which rubble, buildings, scars, chemicals, bones, sounds, algorithms, videos, or photographs can become the evidence of crimes committed by the powerful forces that continuously ravage the world." Similarly, Kurgan (2013:26) cites a humanitarian activist who makes use of satellite imagery to identify the warning signs of mass atrocities, saying that it is:

a clear example of how technology transforms the way we think about and prepare for crises. In the hands of well-trained and experienced analysts guided by humanitarian principles, 
satellite technology provides a potent new way of ensuring that the world witnesses threats to civilians.

Thus, what is of interest is not just the work of Forensic Scientists but also the laws that render certain bodies (and other matter) out of place; the ways in which political decision-makers in different places and nodes create the policy documents that will find their way onto the desks of others (e.g. Kuus 2014); the ways in which the convergence of the same pathogens with bodies has such different outcomes in different contexts (e.g. Hinchliffe, Bingham, Allen and Carter 2016); or the ways in which particular practices "from the micro-geographies of the body and the court room, through to the separation of legal buildings from surrounding infrastructures" shape different legal practices in post-conflict situations of transitional justice (Jeffrey 2011: 246).

And while it is important to recognise the presence of material in political geography and geopolitics, and to understand the co-constitutive nature of bodies and things, representation and materiality, I have argued here that for a distinctively feminist geopolitics, it is the coalescence of these assemblages around bodies, and attentiveness to the politics of these bodies moving through different spaces, that is key. A forensic approach, then, offers a way of considering the material in feminist geopolitics that captures both the fleshy materiality of bodies - individual speaking bodies, populations, injured bodies, body parts, dead bodies - and the ways in which these are brought to bear on the formation of geopolitical representation through various expert and everyday performances that render this flesh meaningful.

\section{ACKNOWLEDGMENTS}

This paper has taken a very long time to come together, and I would like to thank Louise Amoore and the anonymous reviewers for their patience, and Cheryl McGeachan, Emma Laurie and Ian Shaw for their encouragement (and no small amount of nagging). Thanks also to Chris Philo, Sara Koopman, Lorraine Dowler and Dan Clayton for taking the time to engage with the ideas as they were slowly emerging, and to Val McDermid and Sue Black for the forensics insights.

\section{REFERENCES}

Barry, A. 2013a. Material politics: disputes along the pipeline. Oxford: Wiley-Blackwell, RGS-IBG book series.

Barry, A. 2013b. The translation zone: between actor-network theory and international relations. Millennium: journal of international studies 41(3): 413-429. 
Beauchamp, S. 2016. Dearer to the vultures. The Paris Review. June 2, https://www.theparisreview.org/blog/2016/06/02/dearer-to-the-vultures/, accessed 20/4/17.

Black, S. and Nic Daeid, N. 2015. Time to think differently: catalysing a paradigm shift in forensic science. Phil. Trans. R. Soc. B 370: 20140251.

Brickell, K. 2012. Geopolitics of home. Geograpby Compass 6(10): 575-588.

Browne, S. 2015. Dark matters: on the surveillance of blackness. Durham, NC: Duke University Press.

Butler, J. 2012. Bodies in alliance and the politics of the street. In McLagan and McKee eds. 2012. Sensible politics: the visual culture of nongovernmental activism. New York: Zone Books, pp.117-137.

Butler, J. 2015. Notes toward a performative theory of assembly. London: Harvard University Press.

Castner, B. 2016. All the ways we kill and die: an elegy for a fallen comrade and the bunt for his killer. New York: Arcade Publishing.

Coole, D. and Frost, S. 2010. Introducing the New Materialisms, In Coole, D. and Frost, S. eds. New Materialisms: ontology, agency, and politics. Durham and London: Duke University Press.

Dalby, S. 2010. Recontextualising violence, power and nature: the next twenty years of critical geopolitics? Political Geography 29(5): 280-288.

Dittmer, J. 2014. Geopolitical assemblages and complexity. Progress in human geography 38(3): 385401.

Dixon, D. 2015. Feminist geopolitics: material states. Farnham, Surrey: Ashgate, ebook edition.

Dowler, L. 2002. Women on the frontlines: rethinking war narratives post 9/11. GeoJournal 58(23): 159-165.

Dowler, L. and Sharp, J. 2001. A feminist geopolitics? Space and Polity 5(3): 165-176.

Fluri, J. 2009. Geopolitics of gender and violence 'from below'. Political Geography 28(4): 259-265.

Gordillo, G. 2015. Review essay. Empire on trial: the forensic appearance of truth. Environment and Planning D: Society and Space 33: 382-388.

Hinchliffe, S., Bingham, N., Allen, J. and Carter, S. 2016. Pathological lives: disease, space and biopolitics. Oxford: Wiley Blackwell.

Hyndman, J. 2001. Towards a feminist geopolitics. Canadian Geographer 45: 210-222.

Jacobsen, K. 2015. The politics of humanitarian technology: good intentions, unintended consequences and insecurity. London: Routledge.

Jeffrey, A. 2011. The political geographies of transitional justice. Transactions, Institute of British Geographers 36: 344-359.

Kearns, G. and Reid-Henry, S. 2009. Vital Geographies: Life, Luck, and the Human Condition. Annals of the Association of American Geographers. 99: 554-574.

Kinkaid, E. forthcoming. Can assemblage think difference? A feminist critique of assemblage geographies. Progress in Human Geography online first.

Koff, C. 2004. The Bone Woman: among the dead in Rwanda, Bosnia, Croatia and Kosovo. London: Atlantic Books.

Koopman, S. 2011. Alter-geopolitics: other securities are happening. Geoforum 42(3): 274-284. 
Kurgan, L. 2013. Close up at a distance: mapping, technology, and politics. New York: Zone Books.

Kuus, M. 2014. Geopolitics and expertise: knowledge and authority in European diplomacy. Oxford: Wiley Blackwell.

Last, A. 2015. Fruit of the cyclone: undoing geopolitics through geopoetics. Geoforum. 64: 56-64.

Latour, B. 1993. We have never been modern, trans. C. Porter. Hemel Hampstead: Harvester Wheatsheaf.

Lorimer, H. 2005. Cultural geography: the busyness of being 'more-than-representational'. Progress in human geography 29(1): 83-94.

Massey, D. 1993. Politics and space/time, in M. Keith and S. Pile eds. Place and the politics of identity. London: Routledge.

McDermid, V. 2015. Forensics: the anatomy of crime. London: Profile Books.

McLagan, M. and McKee, Y. Introduction. In McLagan and McKee eds. 2012. Sensible politics: the visual culture of nongovernmental activism. New York: Zone Books, pp.9-26.

Meehan, K., Shaw, I.G.R. and Martson, S. 2013. Political geographies of the object. Political Geogrpaby 33: 1-10.

Pain, R. 2014. Everyday terrorism: connecting domestic violence and global terrorism. Progress in Human Geography 38(4): 531-550.

Parker, H. 2016. Anatomy of a soldier. London: Faber and Faber.

Pratt, G. and Rosner, V. eds. 2012. The Global and the Intimate: feminism in our time. New York: Columbia University Press.

Puar, J. 2017. The Right to Maim: debility, capacity, disability. Durham: Duke University Press.

Rosenblatt, A. 2015. Digging for the disappeared: forensic science after atrocity. Stanford CA: Stanford University Press.

Schuppli, S. 2014. Entering evidence: cross-examining the court records of the ICTY. In Forensic Architecture ed. Forensis: the architecture of public truth. Berlin: Sternberg Press, pp. 279-316.

Sharp, J. 2000. Remasculinising geo(-)politics? comments on Gearóid Ó Tuathail's Critical Geopolitics. Political Geography 19(3): 361-364.

Shaw, I.G.R. 2012. Towards an evental geography. Progress in Human Geography 36: 613-627.

Squire, V. 2015. Reshaping critical geopolitics? The materialist challenge. Review of International Studies 41: 139-159.

Thrift, N. 2000. It's the little things. In K. Dodds, \& D. Atkinson (Eds.), Geopolitical traditions: Critical histories of a century of geopolitical thought (pp. 380-387). London: Routledge.

Van der Ploeg, I. 1999. The illegal body: 'Eurodac' and the politics of biometric identification. Ethics and Information Technology 1: 295-302.

Wagner, S. 2008. To know where he lies: DNA technology and the search for Srebrenica's missing. Berkeley: University of California Press.

Weheliye, A. 2014. Habeas viscus: racializing assemblages, biopolitics, and black feminist theories of the buman. Durham: Duke University Press. 
Weizman, E. 2017. Forensic architecture: violence at the threshold of detectability. New York: Zone Books.

Weizman, E. 2012. Forensic architecture: notes from fields and forums. dOCUMENTA (13), ebook.

Weizman, E. 2011. The least of all possible evils: humanitarian violence from Arendt to Gaza. London: Verso.

Woodyer, T. and Carter, S. forthcoming. Domesticating the geopolitical: rethinking popular geopolitics through play. Social and Cultural Geography online first.

${ }^{i}$ Except that, of course, people are not without agency. There are tales of refugees attempting to destroy their fingerprints, traffickers creating false records, and a trade in biometric data.

ii There is, clearly, a politics to this and one that is being highlighted by some of the forensic scientists themselves who see the tensions between their scientific practices and the ways in which evidence is used in the courtroom - and in the courtroom of the media - especially in an era where people feel they understand the material narratives from their own training through regular doses of watching CSI and reading crime fiction, currently the most popular English-language genre. (Black and Nic Daeid 2015). 